University of Nebraska - Lincoln

DigitalCommons@University of Nebraska - Lincoln

Roman L. Hruska U.S. Meat Animal Research

U.S. Department of Agriculture: Agricultural Center

Research Service, Lincoln, Nebraska

1988

Fetal Development in Cows With Multiple Fetuses

Sherrill E. Echternkamp

U.S. Meat Animal Research Center

Follow this and additional works at: https://digitalcommons.unl.edu/hruskareports

Part of the Animal Sciences Commons

Echternkamp, Sherrill E., "Fetal Development in Cows With Multiple Fetuses" (1988). Roman L. Hruska U.S. Meat Animal Research Center. 84.

https://digitalcommons.unl.edu/hruskareports/84

This Article is brought to you for free and open access by the U.S. Department of Agriculture: Agricultural Research Service, Lincoln, Nebraska at DigitalCommons@University of Nebraska - Lincoln. It has been accepted for inclusion in Roman L. Hruska U.S. Meat Animal Research Center by an authorized administrator of DigitalCommons@University of Nebraska - Lincoln. 


\title{
Fetal Development in Cows With Multiple Fetuses
}

\author{
Sherrill E. Echternkamp'
}

\section{Introduction}

About $60 \%$ of the nutrient requirements for beef production in the U.S. are for maintenance of the breeding herd. In addition, the bovine female only produces about .7 of her body wt per yr in progeny wt. Thus, increasing the reproductive rate in beef cattle would have a major economic benefit. Although most bovine females are capable of gestating two calves, the natural frequency of twin births is low, ranging from less than .5\% to $4 \%$ of the calvings, depending upon the breed of cattle. Several studies have indicated that the frequency of multiple births in cattle can be increased by gonadotropin hormonal therapy or by the artificial transfer of two 7- or 8-day-old embryos into the uterus. Unfortunately, the twinning response to these methods has been highly variable both within and among herds of cattle. The present study was conducted to identify causes for the variable twinning response in cattle to low dosages of gonadotropin therapy, to assess fertility in cattle that ovulate multiple oocytes (eggs), and to assess the relationship between number of fetuses and development of the fetus.

\section{Procedure}

Nonlactating mature beef cows (96 cows) were given multiple low-dosages of follicle stimulating hormone $(\mathrm{FSH})$ to stimulate multiple follicles on the ovaries to release eggs that would be fertilized and presumably result in twin or multiple fetuses. The FSH (total dosage $=12 \mathrm{mg}$ ) was administered intramuscularly twice daily (12 hr apart) for 4 days, starting 8 to 12 days after estrus. The FSH treatment schedule was two injections (a.m. and p.m.) of $2 \mathrm{mg} \mathrm{FSH}$ on day 1 of treatment, two injections of $2 \mathrm{mg}$ on day 2, two injections of $1 \mathrm{mg}$ on day 3 , and two injections of $1 \mathrm{mg}$ on day 4 . Each cow received a $35 \mathrm{mg}$ intramuscular injection of prostaglandin $\mathrm{F}_{2}$ a the morning of day 4 to regress the corpus luteum $(C L)$ and synchronize estrus. Cows were bred naturally by fertile bulls at the subsequent estrus; estrus occurred about 60 $\mathrm{hr}$ after the prostaglandin injection.

'Echternkamp is a research physiologist, Reproduction Unit, MARC.
The cows were slaughtered either 6 to 8 days after mating (25 cows) to assess fertilization of the eggs, or 51 to 53 days after mating (71 cows) to assess fetal development. The female reproductive tract was removed, the number of ovulation sites on each ovary was recorded, and the lumen of the uterus and oviducts were flushed with saline to recover embryos, fetuses, and unfertilized eggs (oocytes). Fertilization rate and fetal size and development were measured microscopically or grossly, respectively.

\section{Results}

For the cows slaughtered 6 to 8 days after mating, the number of ovulation sites (ovulation rate) ranged from one to five. The relationship between ovulation rate and percentage of normal embryos, dead or degenerate embryos, and unfertilized eggs at $7 \pm 1$ days after mating is shown in Table 1. Fertilization rate and embryonic development at 6 to 8 days after mating were not affected by number of ovulations.

At $52 \pm 1$ days after mating, ovulation rate ranged from 1 to 27 and, thus, was more variable to the same FSH treatment in this group of cows than in those cows slaughtered earlier. The relationship between number of ovulations and fetal number and development at $52 \pm$ 1 days of gestation is shown in Table 2. As the number of ovulation sites (CL) exceeded two, the number of dead or abnormal fetuses increased as did the number of unrecovered fetuses. The maximal number of live fetuses recovered from a uterus at 51 to 53 days of gestation was five fetuses, and the maximal number of live fetuses per uterine horn was three fetuses. Weight of the individual corpus luteum (CL) on the ovaries decreased as the number of CL per cow increased from one to two to three or more. Weight, length, and width of individual live fetuses (Table 3 ) were not affected by the number of live fetuses present in the uterus at $52 \pm 1$ days of gestation. However, as indicated previously, the number of dead or degenerative fetuses recovered increased as the total number of fetuses (dead + live) increased; the dead fetuses were approximately one-third to one-half the size of live fetuses. In contrast, placental wt per live fetus was decreased proportionally to the number of fetuses present.

Table 1-Effect of ovulation rate on fertilization rate and embryonic survival at $7( \pm 1)$ days postmatinga

\begin{tabular}{|c|c|c|c|c|}
\hline \multirow[b]{2}{*}{$\begin{array}{l}\text { Ovulation } \\
\text { rate }^{\mathrm{b}}\end{array}$} & \multirow[b]{2}{*}{$\begin{array}{l}\text { No. } \\
\text { cows }\end{array}$} & \multicolumn{3}{|c|}{ No. and percentage of embryos or oocytes } \\
\hline & & $\begin{array}{l}\text { Normal } \\
\text { embryo }\end{array}$ & $\begin{array}{c}\text { Abnormal } \\
\text { embryo }\end{array}$ & $\begin{array}{l}\text { Unfertilized } \\
\text { oocyte }\end{array}$ \\
\hline $1 \mathrm{CL}$ & 12 & $7(58.3) \mathrm{c}$ & $2(16.7)^{c}$ & $3(25.0)^{c}$ \\
\hline $2 \mathrm{CL}$ & 10 & $9(45.0)$ & $3(15.0)$ & $8(40.0)$ \\
\hline $3 \mathrm{CL}$ & 1 & $2(66.7)$ & 1 (33.3) & \\
\hline $4 \mathrm{CL}$ & 1 & $4(100.0)$ & & \\
\hline $5 \mathrm{CL}$ & 1 & $3(60.0)$ & $1(20.0)$ & $1(20.0)$ \\
\hline
\end{tabular}


In cows with multiple fetuses at $52 \pm 1$ days of gestation, the placental membranes were generally attached between adjacent fetuses, resulting in a common blood supply among the fetuses. Consequently, death of one bovine fetus in a multiple fetation pregnancy resulted in death and subsequent expulsion of all fetuses contained within the same connected placenta.

\section{Conclusion}

The variation in twinning response to hormonal therapy resulted initially from variation among cows in ovarian stimulation and the number of eggs (oocytes) released from the ovaries. The percentage of eggs fertilized by the sperm was not affected by number of eggs present. However, increasing the number of fertilized eggs per cow subsequently increased the total number of fetuses and the number of dead fetuses at $52 \pm 1$ days of gestation; death of the fetuses generally occurred at about 25 days after mating. Because of the high incidence of placental attachment among bovine fetuses in multiple fetation pregnancies, death of one fetus terminates the pregnancy and, thus, reduces the opportunity for twins or multiple calves. The connecting of placental blood supplies between fetuses is a phenomenon rarely found in other farm animals. The lower birth wt of twin or multiple calves is manifested during the third trimester of pregnancy, whereas fetal wt and development during the first trimester of pregnancy are not affected by number of fetuses present.

Table 2-Effect of ovulation rate on fetal survival at $52( \pm 1)$ days postmatinga

\begin{tabular}{|c|c|c|c|c|c|c|}
\hline \multirow{2}{*}{$\begin{array}{l}\text { Ovula- } \\
\text { tion } \\
\text { rateb }\end{array}$} & \multirow{2}{*}{$\begin{array}{l}\text { No. } \\
\text { Cows }\end{array}$} & \multirow{2}{*}{$\begin{array}{l}\text { No. } \\
\text { CL. }\end{array}$} & \multirow{2}{*}{$\begin{array}{c}\mathrm{CL} \\
\text { wt(g) }\end{array}$} & \multicolumn{3}{|c|}{ Fetal status } \\
\hline & & & & Normal & Abnormal & Absent \\
\hline $1 \mathrm{CL}$ & 16 & 16 & $5.28^{d}$ & $17(106.3)^{c}$ & & \\
\hline $2 \mathrm{CL}$ & 10 & 20 & $4.17 \mathrm{e}$ & $20(100.0)$ & & \\
\hline $3 \mathrm{CL}$ & 6 & 18 & $2.65^{f}$ & $12(66.7)$ & $3(16.7)$ & $3(16.7)$ \\
\hline $4 \mathrm{CL}$ & 6 & 24 & $2.28^{f}$ & $11(45.8)$ & $5(20.8)$ & 8 (33.3) \\
\hline $5 \mathrm{CL}$ & 9 & 45 & $2.15^{f}$ & 15 (33.3) & 14 (31.1) & $16(35.6)$ \\
\hline 6-10 CL & 10 & 81 & $1.89^{f}$ & $11(13.6)$ & $59(72.8)$ & 11 (13.6) \\
\hline $10 \mathrm{CL}$ & 3 & 56 & $2.22^{f}$ & $5(8.9)$ & 32 (57.1) & 19 (33.9) \\
\hline
\end{tabular}

${ }^{2}$ Cows received FSH (total dosage $=12 \mathrm{mg}$ ) twice daily for 4 days $(2 \mathrm{mg} \times 2,2 \mathrm{mg} \times 2,1 \mathrm{mg} \times 2,1 \mathrm{mg} \times 2)$ beginning on days 8 to 12 after estrus (estrus $=$ day 0 ) and $35 \mathrm{mg}$ prostaglandin $F_{2 a}$ on fourth day (a.m.) of FSH. Cows bred via natural insemination.

buvulation rate was the number of corpora lutea (CL) present at 51,52 , or 53 days postmating.

cPercentage of number of fetuses per number of $\mathrm{CL}$ present at fetal assessment.

def Means without a common superscript differ; de $\mathrm{P}<.05$, ef $\mathrm{P}<.01$.

Table 3-Effect of number of fetuses on fetal and placental size at 52 days of gestation

\begin{tabular}{lccccc}
\hline & \multicolumn{5}{c}{ Number of live fetuses } \\
\cline { 2 - 6 } Trait & 1 & 2 & 3 & 4 & 5 \\
\hline No. cows & 17 & 18 & 7 & 3 & 1 \\
Fetal wt $(\mathrm{g})$ & 6.57 & 7.01 & 7.03 & 7.31 & 7.13 \\
Fetal length $(\mathrm{mm})$ & 43.3 & 44.4 & 45.2 & 45.7 & 46.2 \\
Fetal width $(\mathrm{mm})$ & 14.5 & 14.7 & 14.2 & 14.4 & 14.9 \\
Placental dry wt $(\mathrm{g})$ & 2.19 & 1.63 & 1.33 & 1.21 & 1.21 \\
Amniotic fluid volume $(\mathrm{ml})$ & 28.1 & 30.1 & 32.3 & 30.9 & 39.3 \\
\hline
\end{tabular}

